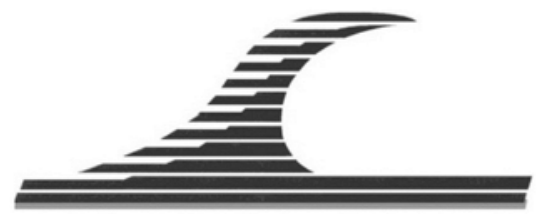

\title{
Coastal flood protection systems Xynthia feedback experience. Case studies conclusion
}

\author{
Marc IGIGABEL ${ }^{1}$, Yves NEDELEC ${ }^{2}$, Nicolas FLOUEST ${ }^{2}$, \\ Nathalie BERENGER ${ }^{3}$, Patrick CHASSE ${ }^{1}$, Alexis BERNARD ${ }^{3}$, Christian PITIE ${ }^{4}$
}

1. Cerema, Direction technique Eau, Mer et Fleuves, France.

\{marc.igigabel ; patrick.chasse\}@cerema.fr

2. Cerema, Direction territoriale Sud-Ouest, France.

\{yves.nedelec; nicolas.flouest\}@cerema.fr

3. Cerema, Direction territoriale Ouest, France.

\{nathalie.berenger; alexis.bernard\}@cerema.fr

4. Conseil Général de l'Environnement et du Développement Durable, France.

christian.pitie@developpement-durable.gouv.fr

\section{Abstract:}

The determination of the borders and the internal structure of a coastal flood protection system, then the understanding of its behavior during past events contribute widely to determine actions to improve its performance. To set up in this domain a proven methodology, transposable in other places prone to episodes of marine floods, four sites with contrasted configurations were chosen for case studies. These sites are representative of most of the situations met during the storm Xynthia which hit the French Atlantic coast in February, 2010:

- Loix is a peninsula surrounded by a set of basins and marshes,

- Les Boucholeurs extends in border of a vast bay and presents houses on the sea front directly exposed to waves as well as setback constructions on the location of former leveed marshes,

- Boyardville-La Perrotine is an urbanized zone crossed by a leveed canal connecting the sea front with a vast zone of swamp and a marina,

- Batz-sur-Mer is characterized by salterns along which urbanization developed.

These sites are structured by a network of natural features, levees, canals and ditches, road and railway infrastructures, involving many actors for their management.

This paper presents case studies conclusions. It focuses on the way the main identifiable stakes were actually protected during the passage of the storm Xynthia.

Translated version of a paper in French (DOI reference: http://dx.doi.org/10.5150/cmcm.2015.042), presented during the edition 3 of the Coastal and Maritime Mediterranean Conference,

(25-27 November 2015) in Ferrara, Italy.

Received 11 June 2015, accepted 11 December 2015, available online 30 May 2016.

How to cite this paper:

IGIGABEL M., NEDELEC Y., FLOUEST N., BERENGER B., CHASSE P., BERNARD A., PITIE C. (2016). Coastal flood protection systems Xynthia feedback experience. Case studies conclusion. Revue Paralia, Vol. 9, pp s04.1-s04.6.

DOI: http://dx.doi.org/10.5150/revue-paralia.2016.s04 


\section{Introduction}

Four sites on the French Atlantic coast (Loix, Les Boucholeurs, Boyardville and Batzsur-mer) hit by the storm Xynthia in February, 2010 were analyzed to understand the way the main stakes were protected by their flood protection system (IGIGABEL et al., 2016). This paper presents case studies conclusions.

\section{Loix}

The site of Loix (see figure 1) consists of a village surrounded by a set of basins and marshes. The analysis focuses on the district of Lavaud positioned at the back of the basins. These basins form a cordon along the coast. If we consider the organization of the site for the protection of the district Lavaud, it appears a waterfall scheme: when cells 1,2 and 3 are filled, water overflows towards cell 4 which itself can receive directly water from the sea front. Flows between cells can occur through secondary levees or through the back zone between cells and the sheltered line.

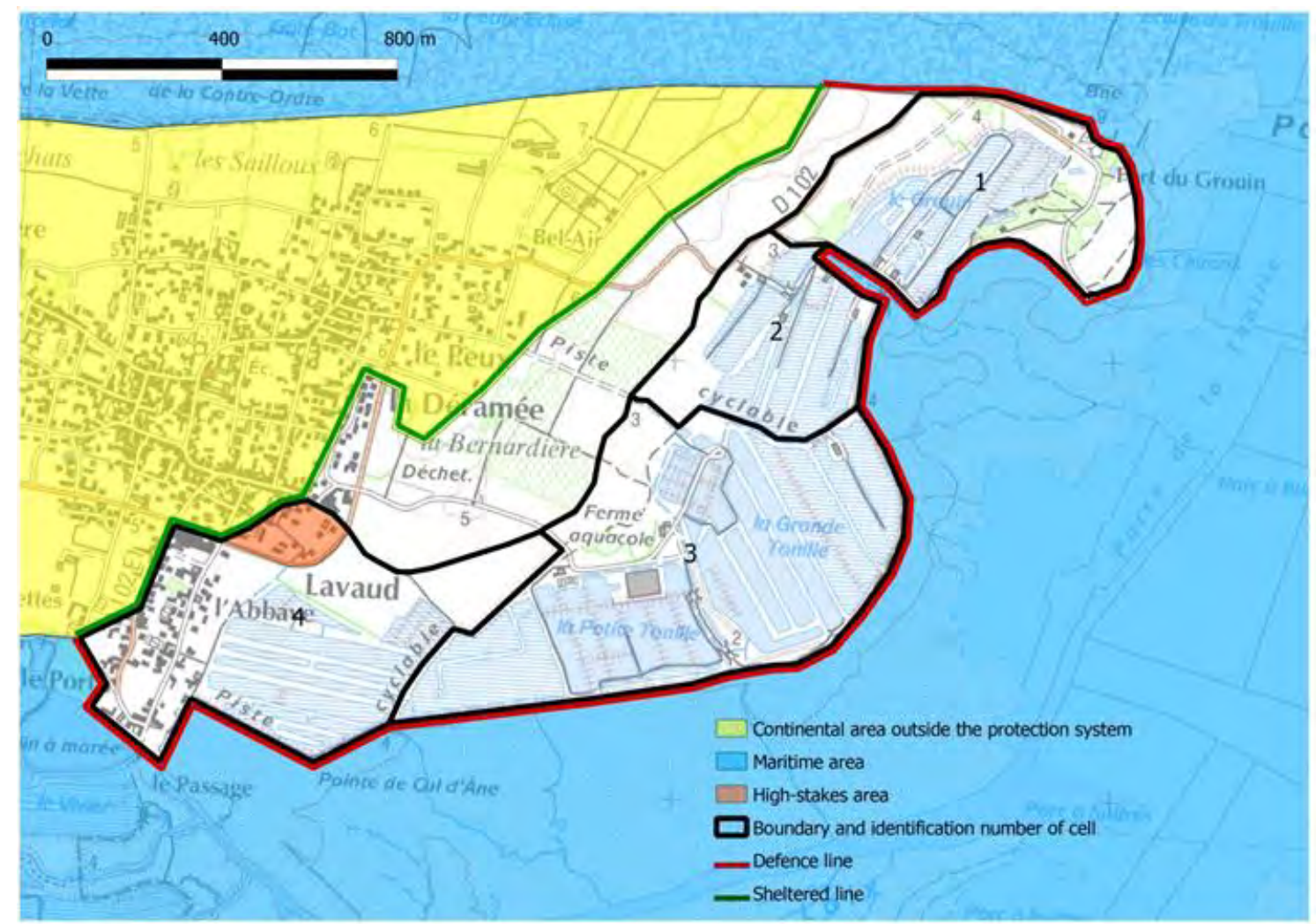

Figure 1. Loix system schematization.

During Xynthia, Lavaud district underwent a very fast flood: whereas the surrounding cells filled, multiple breaches formed on the maritime dike. In these conditions, shortly before the peak of tide, flows occurred in a quasi-synchronous way with high discharges to the low-lying zone Lavaud. 


\section{Les Boucholeurs}

Les Boucholeurs site is a large area fairly densely urbanized. The analysis focuses on the inhabited sector of Les Boucholeurs (see figure 2). During Xynthia, the following protection failures appeared:

- North, sea walls did not protect enough against overtopping. Wave breaking caused two deaths,

- South, dunes were very fragile and the swamp storage capacity was widely exceeded. At rising tide, only water from cell 2 could join cell 1 . If road and railway infrastructures partially orientated water from cell 2 to the stakes zone, they also let a part of the volume spill in cell 3. Water entering in cell 4 overflowed the cell 3 without reaching cells 1 and 2 .

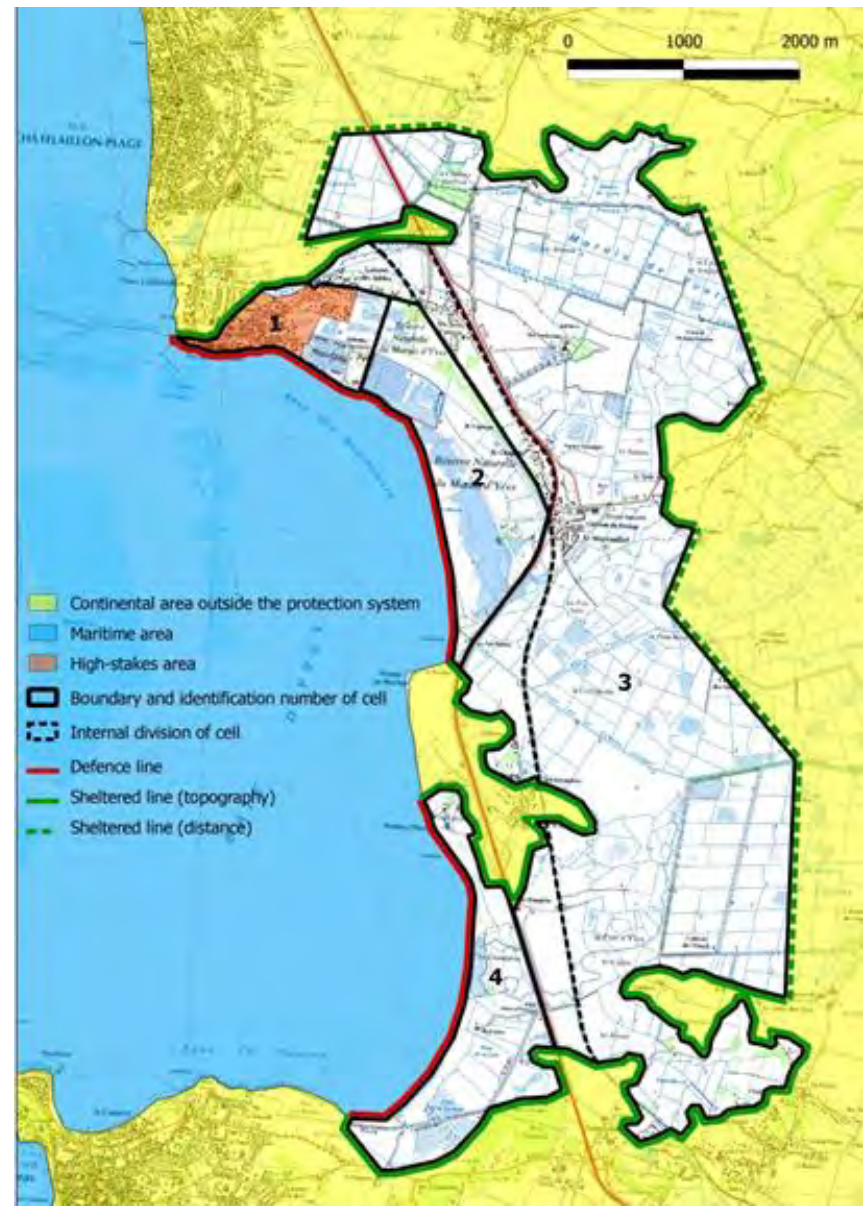

Figure 2. Les Boucholeurs system schematization.

Port Punay canal, that crosses the urbanized zone, provoked its flooding by orientating flows in this low-lying sector. At its outlet, low discharge didn't contribute significantly to the inundation but after the storm the discharge was also too low to evacuate the water. This led to a detrimental inundation for many days. 


\section{Boyardville-La Perrotine}

Boyardville-La Perrotine is an urbanized sector crossed by a leveed canal connecting the sea front with a vast area of swamp (see figure 3). This site is analyzed considering one single protection system because the canal allows hydraulic exchanges on one hand between the sea front and the swamp, and on the other hand, between its two banks. The analysis focuses on Boyardville sector.

Potential hydraulic pathways leading to cell 1 (Boyardville) are:

- between the downstream part of the canal and Boyardville (the most direct path),

- between the swamp and Boyardville, from cell 3 to cell 1 (by the West),

- and between the swamp and Boyardville, from cell 3 to cell 1 through cell 4 (passing North widely).

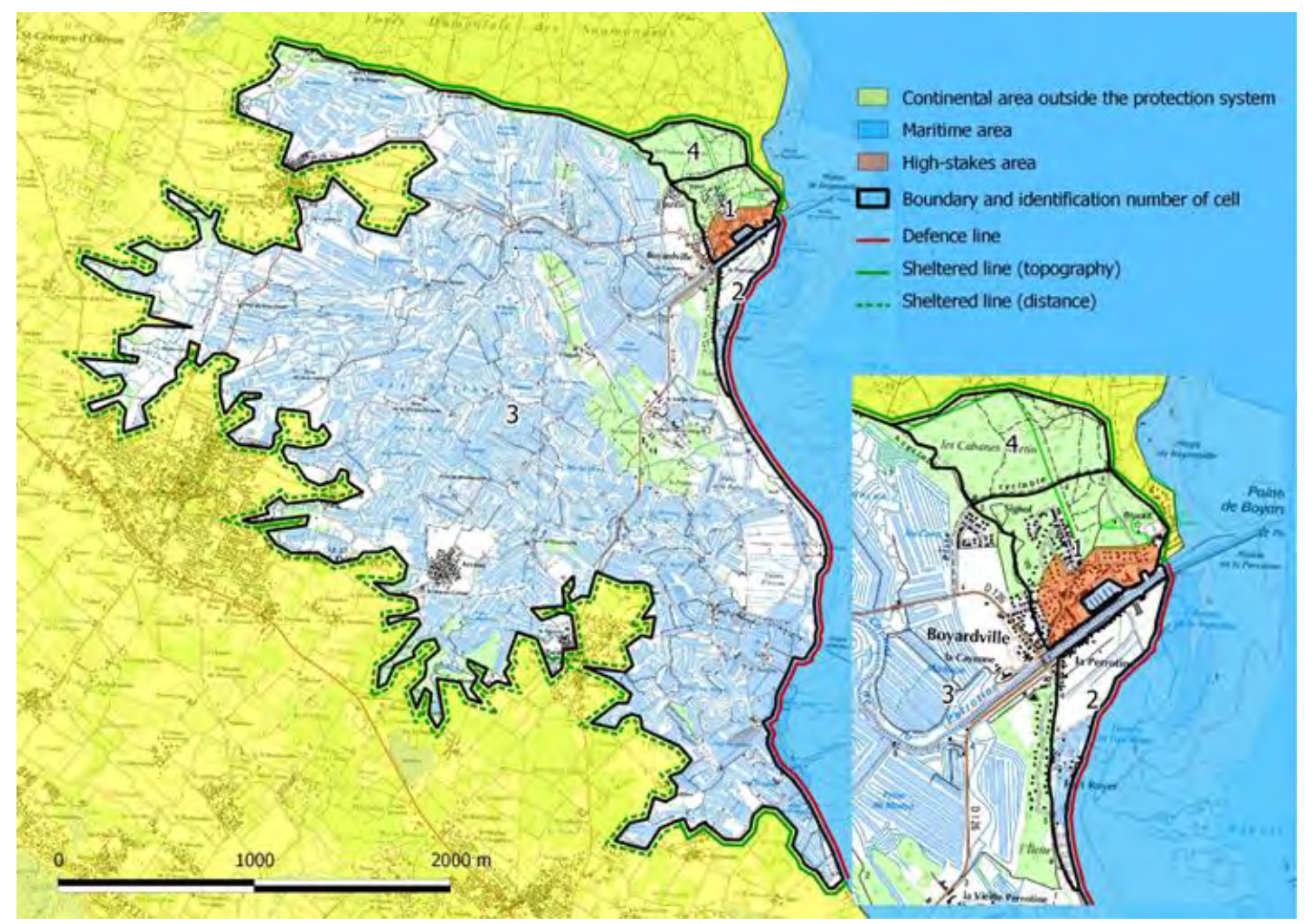

Figure 3. Boyardville system schematization.

During Xynthia, because of the exceptional sea level, the functioning of the canal was perturbed: shortly before the peak of tide, an additional water flow crossed La Perrotine (Cell 2). The main flow in Boyardville occurred downstream to the canal where the head loss was least important and where the flow from La Perrotine came out. Boyardville basin flooding, although it was partial (water depths between 1.40 and $1.65 \mathrm{~m}$ ), caused a death. A $0.15 \mathrm{~m}$ higher sea water level would have engendered water depths between 1.75 and $2.00 \mathrm{~m}$. 


\section{Batz-sur-Mer}

Batz-sur-Mer (see figure 4) is characterized by salterns along which urbanization developed. The analysis focuses on the urbanized La Herpe sector. The system is constituted of:

- four cells along the sea front that are separated by inlets,

- a back area where La Herpe sector is situated.

This position behind cells results of the fact that its altitude is higher than the low points of the defense line constituted by the maritime dike. It means that for this district, the maritime dike does not retain water and that La Herpe district is not prone to fast floods engendered by a breach or the overflow of the sea dike.

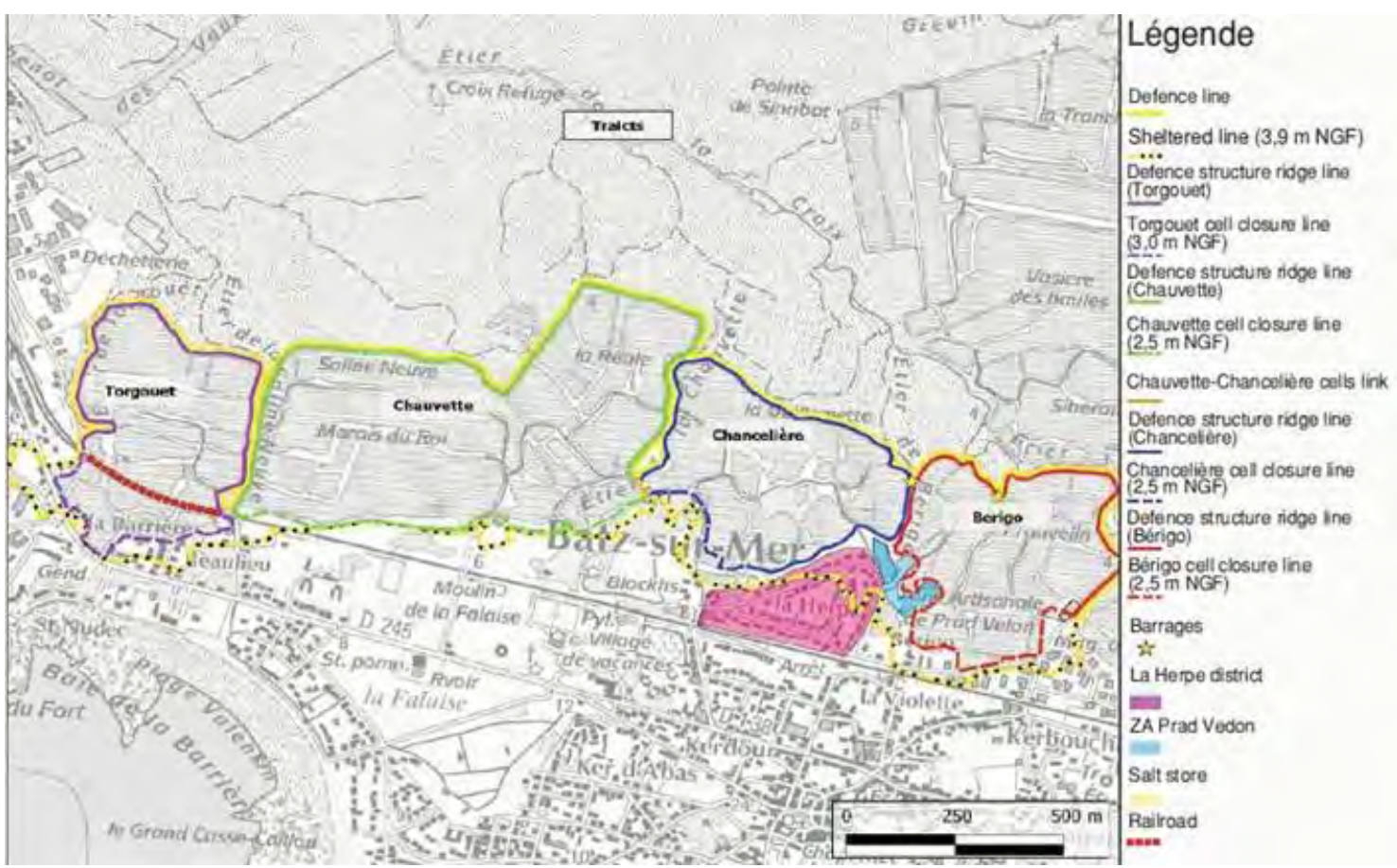

Figure 4. Batz-sur-Mer system schematization.

During Xynthia, basins filled quickly enough to consider that the system doesn't slow down the flooding on this stakes zone. Inlets, although some of them are equipped with dams represents preferential flow paths. Thus levees and basins have a neutral effect on water levels that appear on La Herpe sector. Nevertheless, this device keeps a positive effect by offering a good protection against waves propagation. 


\section{Conclusion}

Studied sites show diverse configurations which engendered during Xynthia diverse flooding mechanisms.

- In Loix, the position of Lavaud district is particular: far from the sea front, it is potentially at the place where flows from all cells meet and can store their water. Breaches and the saturation of basins provoked a very fast flood in this district just before the peak of tide.

- In Les Boucholeurs, the urbanized zone has undergone both, north, overtopping on the sea front (the strong exposure to waves caused two deaths) and, south, water entrances on a very large linear due to levees and dunes overflowing. The canal that crosses the urbanized area contributed to store the water in the high stakes zone. However, the permeability of road and railway infrastructures allowed a part of the water to spread outside the most vulnerable areas.

- In Boyardville-La Perrotine, the flooding of Boyardville basin depends on the water level of the canal that crosses the site. In addition to its normal supply from the sea front, the canal received water crossing La Perrotine sector. Although Boyardville basin was not completely filled, its flooding caused one death.

- In Batz-sur-mer, la Herpe district is separated from the sea front by a series of basins. This district is located at a higher altitude than the crest of the dike. For this reason, there is no risk of fast flood.

The most dangerous configurations are the ones which engender fast floods. Some are easy to identify:

- basins positioned immediately at the back of a dike (Boyardville, whose situation is comparable to La Faute-sur-Mer where Xynthia caused 29 deaths),

- sectors exposed to waves (sea front of Les Boucholeurs).

Others are more difficult to reveal:

- basins positioned at the back of basins (case of Lavaud district in Loix),

- low areas crossed by a canal without levee (case of Les Boucholeurs).

A long distance from the coast does not necessarily protect against fast floods.

Finally, some areas can be flooded but the risk for the life of their occupants is limited thanks to their situations out of dike influence zones and out of basins (case of La Herpe district in Batz-sur-Mer). If these areas are flooded, the water will raise slowly (at the speed of the sea water level at the peak of tide).

\section{Reference}

IGIGABEL M., NEDELEC Y., FLOUEST N., BERENGER N., CHASSE P., BERNARD A., COSQUER E., TIBERI-WADIER A.-L. (2016). Étude des systèmes de protection contre les submersions marines. Méthodologie et études de cas issues du retour d'expérience Xynthia, Éditions du Cerema. 